\title{
An in-frame insertion in exon 3 and a nonsense mutation in exon 2 of the insulin receptor gene associated with severe insulin resistance in a patient with Rabson-Mendenhall syndrome
}

\author{
D.Müller-Wieland ${ }^{1}$, E. R. van der Vorm ${ }^{2}$, R.Streicher ${ }^{1}$,W.Krone ${ }^{1}$, E.Seemanova ${ }^{3}$, M.Dreyer ${ }^{4}$, H.W. Rüdiger ${ }^{5}$, \\ S.R.Rosipal ${ }^{6}$, J.A.Maassen ${ }^{2}$ \\ ${ }^{1}$ Klinik II und Poliklinik für Innere Medizin der Universität zu Köln, Cologne, Germany \\ ${ }^{2}$ Department of Medical Biochemistry, Sylvus Laboratories, Leiden, The Netherlands \\ ${ }^{3}$ Department of Clinical Genetics, Charles University Hospital, Praha-Motol, Czech Republic \\ ${ }^{4}$ Department of Diabetes and Metabolism, Krankenhaus Bethanien, Hamburg, Germany \\ ${ }^{5}$ Universitätsklinik für Innere Medizin IV, Abteilung für Arbeitsmedizin, Vienna, Austria \\ ${ }^{6}$ Department of Paediatrics, Hospital Poprad, Poprad, Slovak Republic
}

\begin{abstract}
Summary. We have studied the structure and function of the insulin receptor in a patient (PK) with severe insulin resistance and Rabson-Mendenhall syndrome. Insulin binding to cultured fibroblasts from PK was almost not detectable and insulin-induced insulin receptor autophosphorylation and glucose uptake was abolished. The structure of the receptor gene was analysed by sequencing amplified products of the 22 exons with the flanking intron regions directly as well as after subcloning in pUCBM20 plasmids. Two mutant alleles of the insulin receptor gene were detected. One allele contains in-frame 12 additional base pairs in exon 3 coding for the amino acids Leu-His-Leu-Val located between Asp-261 and Leu-262 in the receptor's extracellular domain, being the first report of an insertion mutation of the insulin receptor gene. In the other allele Arg-86 in exon 2 is changed into a
\end{abstract}

stop codon. Therefore, $\mathrm{PK}$ is compound heterozygous at the insulin receptor locus. Direct cDNA sequencing indicates that both mutant alleles are expressed in the patient's fibroblasts. Studies of the parents' fibroblasts revealed that PK inherited the insertion mutation from the father and the nonsense mutation from the mother. Insulin binding to fibroblasts of the mother was reduced ( $63 \%$ of control cells) and hormone binding to the father's cells shows a larger reduction ( $37 \%$ of control cells), but less severe than the patient's cells (11\% of control). This investigation provides further evidence that the Rabson-Mendenhall syndrome is causally related to mutations in the insulin receptor gene.

Key words: Diabetes mellitus, insulin resistance, insulin receptor, Rabson-Mendenhall syndrome, insertion mutation.
Insulin resistance is the most common disorder of hormone action and a major cause of hyperglycaemia or reduced insulin-mediated glucose uptake in most patients with Type 2 (non-insulin-dependent) diabetes mellitus. It is primarily due to a defect of hormone action at the cellular level [1-5]. During the last few years major advances in biochemistry and molecular biology have led to the elucidation of some principle mechanisms of hormone action and their alterations in disease. Insulin affects multiple pathways regulating cellular metabolism and growth, but the first step in insulin action is the binding and activation of the insulin receptor [5-10]. The insulin receptor is a heterotetramer consisting of two extra-cellular $\alpha$-subunits $(M=135,000)$ and two transmembrane $\beta$-subunits $(\mathrm{M}=95,000)$. The $\alpha$-subunit binds insulin and the intracellular domain of the $\beta$-subunit is an insulinstimulated tyrosine-specific protein kinase [11]. Recently, several natural occurring mutations in the insulin receptor gene have been characterised in patients with insulin resistance and these characterisations have helped to elucidate the molecular mechanisms of insulin action $[5,12$ 17]. In this study we show a structural defect in the ex- tracellular domain of the insulin receptor in an insulin-resistant patient with reduced cellular insulin binding due to two mutant alleles.

\section{Subjects, materials and methods}

\section{Subject}

Patient PK was a Caucasian male with Rabson-Mendenhall syndrome. He was born at term after an uncomplicated pregnancy. He showed growth retardation (birth weight $2170 \mathrm{~g}$ ), mental deficiency, acanthosis nigricans, lipoatrophy and muscular hypotrophy in the extremities, dry and thickened skin, hypertrichosis, enlarged ears and hands as well as external genitalia, and typical coarse facial features. The abdomen appeared distended, but there was no gross hepatosplenomegaly. He had four neonatal teeth and advanced dentition having supranummerary permanent teeth. Insulin resistance was apparent by moderate hyperglycaemia (blood glucose levels between $11-21 \mathrm{mmol} / \mathrm{l}$ ) associated with elevated plasma insulin levels (fasting plasma insulin levels $200-300 \mathrm{mU} / \mathrm{l}$ ). PK was injected with about 70 IU insulin per day, which failed to restore normoglycaemia, to prevent ketonaemia as well as ketonuria. The patient died in 1988 at the age of 10 years during a varicella infection. On autopsy the 
pineal gland was not examined. His parents were not consanguineous. Both parents had atypical oral glucose tolerance tests as well as postprandial hyperglycaemia and the father later developed Type 2 diabetes.

\section{Materials}

Taq polymerase and thermocycler were from Perkin Elmer/Cetus (Norwalk, Conn., USA). Deoxynucleotides and Klenow enzyme were from Boehringer Mannheim (Mannheim, Germany). Other enzymes were from Pharmacia LKB Biotechnology Inc. (Uppsala, Sweden). ${ }^{35} \mathrm{~S}$ - and ${ }^{32} \mathrm{P}$-labelled nucleotides as well as A14-mono $\left[{ }^{125} \mathrm{I}\right]$ iodo insulin and $\left[{ }^{14} \mathrm{C}\right] 2$-deoxyglucose were from Amersham

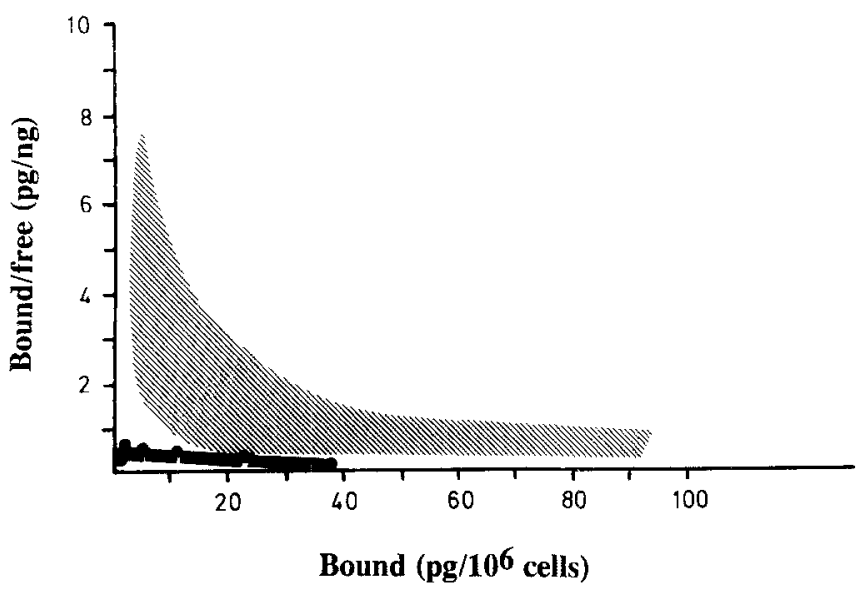

Fig.1. Insulin receptor binding of fibroblasts of 15 healthy donors (shaded area) and patient PK. All experiments were performed in triplicate

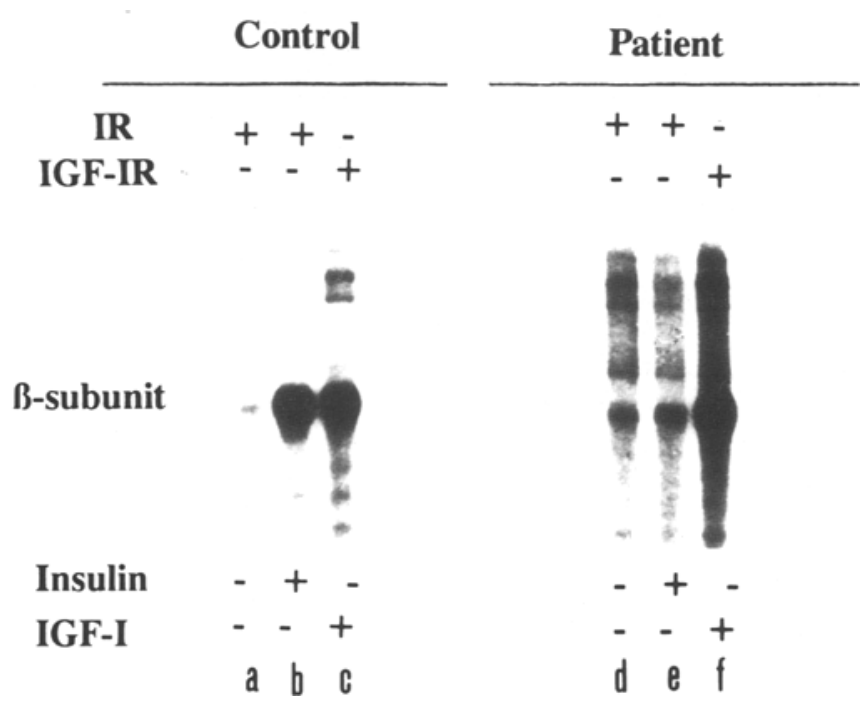

Fig. 2. Autophosphorylation of partially purified receptors for insulin and insulin-like growth factor I (IGF-I) of a control subject and patient PK. Insulin (IR) and IGF-I receptors (IGF-IR) were partially purified from fibroblasts by chromatography on wheat germ agglutinin sepharose. Ligand stimulated autophosphorylation was performed as described in Subjects and methods. Receptor preparations were incubated without (lanes a and d) or with either insulin (lanes $b$ and e) or IGF-I (lanes $c$ and $f$ ). After incubation the IR and IGF-IR were immunoprecipitated with a monoclonal antibody against the IR (lanes a, b, d, and e) or the IGF-IR (lanes $c$ and $f$ ) and analysed by SDS-PAGE and autoradiography. $\beta$ indicates the $\beta$-subunit of the IR and the IGF-IR
(Amersham, Bucks., UK). A polyclonal antibody against the insulin receptor has been described previously [18]. Monoclonal insulin receptor $(\alpha I R)$ and insulin-like growth factor I (IGF-I) receptor $(\alpha I G F-I)$ antibodies were obtained from Amersham and Sanbyo (Uden, Netherlands), respectively. Monocomponent insulin was obtained from Sigma (St. Louis, Mo., USA). The protein markers were obtained using a high molecular weight kit from Bio-Rad (Hercules, Calif., USA). The 1 kilobase (kb) DNA ladder marker was obtained from Gibco (Gaithersburg, Md., USA), pUCBM20 was used as vector and DH5 $\alpha$ as bacteria. All other chemicals were purchased from Sigma, Pharmacia or Boehringer Mannheim.

\section{Cell culture}

Fibroblast cultures were initiated from skin biopsies according to standard techniques. Cells were grown in Dulbecco's modified Eagle's Medium (DMEM, Gibco) supplemented with $10 \%$ fetal calf serum and penicillin, neomycin, and streptomycin, at $37^{\circ} \mathrm{C}, 5 \%$ $\mathrm{CO}_{2}$, and $95 \%$ humidity. Cells were grown overnight in serum-free medium before experiments using insulin.

\section{Insulin binding}

Fibroblasts of the proband and his parents were grown to confluence in six-well dishes. Tracer amounts of ${ }^{125} \mathrm{I}$-insulin were added and cells were further incubated with or without increasing concentrations of unlabelled insulin at $4^{\circ} \mathrm{C}$ for $16 \mathrm{~h}$. After washing and solubilisation the specifically bound radioactivity was determined as described previously [19].

\section{Uptake of 2-deoxyglucose}

Fibroblasts were grown in 6-cm dishes until they had just reached confluency. Twenty-four hours before assaying for 2-deoxyglucose uptake, cells were washed five times with phosphate-buffered saline. Then $1.5 \mathrm{ml} 50 \mathrm{mmol} / 1 \mathrm{Hepes}$, $\mathrm{pH} 7.4,120 \mathrm{mmol} / \mathrm{h} \mathrm{NaCl}, 1.3 \mathrm{mmol} / \mathrm{l}$ $\mathrm{MgSO}_{4}, 1.85 \mathrm{mmol} / \mathrm{C} \mathrm{CaCl}, 4.8 \mathrm{mmol} / \mathrm{KCl}$, containing insulin at various concentrations (indicated in the figures), was added. Cells were incubated for $1 \mathrm{~h}$ at $37^{\circ} \mathrm{C}$. Subsequently 2-deoxyglucose (1$\left[{ }^{14} \mathrm{C}\right]$, sp. act. $\left.4 \mathrm{Ci} / \mathrm{mol}\right)$ was added at a concentration of $7.5 \mu \mathrm{mol} / 1$ and incubation was continued for $10 \mathrm{~min}$ at $37^{\circ} \mathrm{C}$. Uptake of glucose was terminated by addition of $5 \mathrm{ml}$ ice-cold phosphate-buffered saline and cells were lysed in $1 \mathrm{ml} 0.1 \mathrm{~mol} / \mathrm{l} \mathrm{NaOH}$. $\left[{ }^{14} \mathrm{C}\right]$-content was determined by liquid scintillation counting [20].

\section{Autophosphorylation of purified receptor preparations}

Preparation of partially purified insulin receptors by chromatography on wheat germ agglutinin sepharose and insulin-stimulated autophosphorylation was performed as previously described [20]. Insulin was added to $10 \mu \mathrm{l}$ glycoprotein fraction ( $1 \mathrm{mg}$ protein $/ \mathrm{ml}$ ) and incubation was continued for $1 \mathrm{~h}$ at $22^{\circ} \mathrm{C}$. Phosphorylation was initiated by addition of $6 \mathrm{mmol} / 1 \mathrm{MnCl}_{2}$ and ${ }^{32} \mathrm{P}-\mathrm{ATP}(25 \mu \mathrm{mol} / \mathrm{l}$; $200 \mathrm{Ci} / \mathrm{mmol}$ ). Incubation was terminated after $6 \mathrm{~min}$ by addition of $1 \mathrm{mI} 10 \%$ trichloroacetic acid. The protein pellet was washed with $1 \mathrm{ml}$ ethanol and dissolved in $50 \mu \mathrm{l} 50 \mathrm{mmol} / 1 \mathrm{NaHCO}_{3} / 0.1 \%$ SDS for immune precipitation as described before [18].

\section{Polymerase chain reaction}

Genomic DNA $(1 \mu \mathrm{g})$ was subjected to 30 cycles of polymerase chain reaction (PCR) amplification [21] using the primer sets shown below. Each reaction was performed in a volume of $100 \mu$ l containing 
$50 \mathrm{mmol} / \mathrm{l} \mathrm{KCl}, 10 \mathrm{mmol} / \mathrm{l}$ Tris- $\mathrm{HCl}(\mathrm{pH} 8.3$ ), $1.5 \mathrm{mmol} / \mathrm{l} \mathrm{MgCl}$, $10 \mu \mathrm{g} / \mathrm{ml}$ gelatin; $50 \mu \mathrm{mol} / 1$ each of dATP, dGTP, dCTP, and dTTP; $0.15 \mu \mathrm{g}$ each of oligonucleotide primer and 2.5 units of Taq DNA polymerase. After initial denaturation at $94^{\circ} \mathrm{C}$ for $5 \mathrm{~min}$, samples were subjected to 30 cycles of amplification with an automated DNA thermal cycler; annealing at $50-60^{\circ} \mathrm{C}$ for $2 \mathrm{~min}$, extension at $72^{\circ} \mathrm{C}$ for $2 \mathrm{~min}$, and denaturation at $94^{\circ} \mathrm{C}$ for $1 \mathrm{~min}$. When cDNA was amplified, total cellular RNA was extracted [22] and incubated for $30 \mathrm{~min}$ at $37^{\circ} \mathrm{C}$ with reverse transcriptase in the absence of the respective $5^{\prime}$ oligonucleotide [23].

\section{DNA sequencing}

Nucleotide sequences of the insulin receptor gene were obtained directly and after subcloning. DNA (10 ng) was directly sequenced according to Casanova et al. [24] using the United Biochemical Sequence kit version 2.0. PCR-amplified DNA fragments of each exon were subcloned into pUCBM20 plasmids [25] for sequence analysis by the dideoxy chain determination method [26].

\section{Oligonucleotides}

Intron primers sets according to Seino et al. [27] were used for PCR amplification. For analysis of exon 3 an additional set of primers (5'-CGACCATCTGTAAGTCACAC-3'/5'-GAAGCTGAAGTTCACACAGC-3') and a specific oligo for the mutant allele $\left(5^{\prime}\right.$ TTCTGCCAGGACCTACAC-3') were used.

\section{Results}

Insulin binding and insulin action. Insulin binding to cultured fibroblasts of $\mathrm{PK}$ and 15 separate control subjects is shown in Figure 1. Insulin binding was markedly decreased and almost undetectable in the patient's cells. To determine insulin receptor autophosphorylation, the glycoprotein fraction was isolated and incubated with insulin or IGF-I in the presence of ${ }^{32} \mathrm{P}-\mathrm{ATP}$ as indicated in Figure 2. Immunoprecipitations were performed using monoclonal antibodies either to the receptor for insulin or for IGF-I and the precipitates were analysed by SDSPAGE. In agreement with reduced cellular insulin binding, the hormone did not induce autophosphorylation of the insulin receptor $\beta$-subunit. There was no alteration of the insulin receptor phosphorylation in the basal state. Similar results were obtained using a polyclonal antibody to the insulin receptor (data not shown). By contrast, incubation of cells with IGF-I led to a marked increase in the autophosphorylation of the IGF-I receptor (Fig.2), but not of the insulin receptor (data not shown). Correspondingly, binding of IGF-I to cultured fibroblasts in tracer concentrations was not altered (data not shown). Insulinstimulated 2-deoxyglucose uptake in the patient's fibroblasts is shown in Figure 3. In contrast to control cells, insulin-induced uptake of 2-deoxyglucose was greatly diminished in the patient's cells.

Structure of the insulin receptor gene in PK. To determine whether decreased insulin binding and insulin action in PK could be due to a structural alteration of the insulin receptor gene, the 22 exons with the flanking intron regions were amplified and analysed directly as well as after sub-

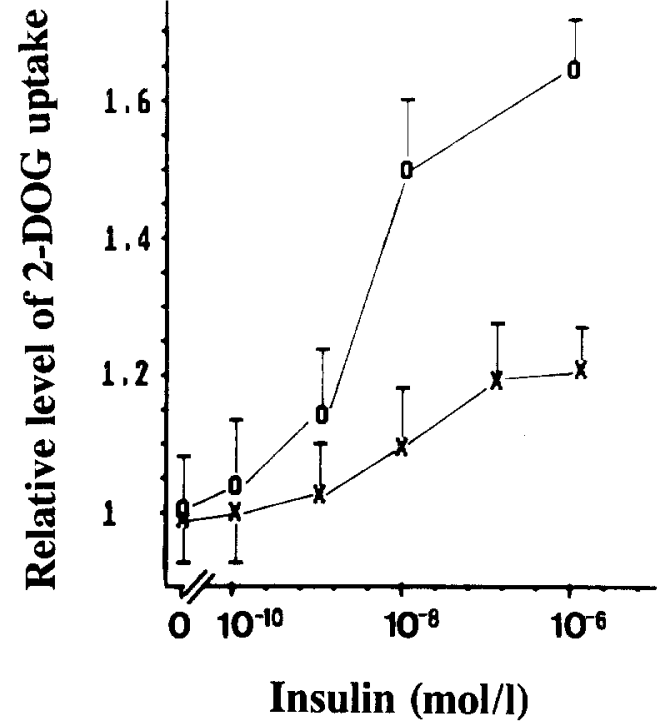

Fig.3. Insulin-stimulated uptake of 2-deoxyglucose (2-DOG) from a control (O) subject and patient PK (X). Unstimulated uptake in control cells corresponds to $0.25 \mathrm{nmol} 2-\mathrm{DOG} / 8 \times 10^{5}$ cells

cloning, sequencing at least four separate clones. Using both methods two different mutations were consistently found altering the primary amino acid sequence of the insulin receptor protein. One mutant allele showed a single nucleotide substitution changing codon CGA for Arg-86 into TGA in exon 2. This stop codon results in a truncation of the extracellular domain after Ser-85 (Fig. 4). The other mutation was found in exon 3 (Fig. 5). Amplified DNAfragments of exon 3 were separated by a $6 \%$ PAGE. In contrast to a single amplified fragment of appropriate length in control individuals, two fragments were seen in PK. The size of one fragment corresponded to the single fragment observed in control subjects, the other fragment was slightly larger. The two fragments were isolated, amplified separately and sequenced directly as well as after subcloning. DNA sequence analysis revealed that the difference in length of the larger fragment was due to an additional 12 base pairs (bp) (5'-CTACACCTGGTT- $\left.3^{\prime}\right)$ inserting in-frame between nucleotide 1002 and 1003. Accordingly, amplification of this mutant allele using an insertion mutation specific primer revealed only a single fragment in PK and none in control subjects (data not shown). The 12 bp code for the amino acids Leu-His-LeuVal between Asp-261 and Leu-262. Direct sequencing of PK's cDNA-fragment containing the nonsense mutation in exon 2 showed that both alleles are expressed in patient's fibroblasts (Fig. 6). Amplification by the PCR of reverse transcribed cellular RNA using primers for exon 3 confirmed the expression of both alleles (data not shown).

Inheritance of the mutant insulin receptor alleles. To study the inheritance of the two mutant insulin receptor alleles DNA was isolated from fibroblasts of the mother and father. The mother was found to be heterozygous for the nonsense mutation in exon 2 and the father heterozygous for the insertion mutation in exon 3 (data not shown). Therefore, $\mathrm{PK}$ is compound heterozygous, the stop codon being the maternal allele and the insertion mutation being 


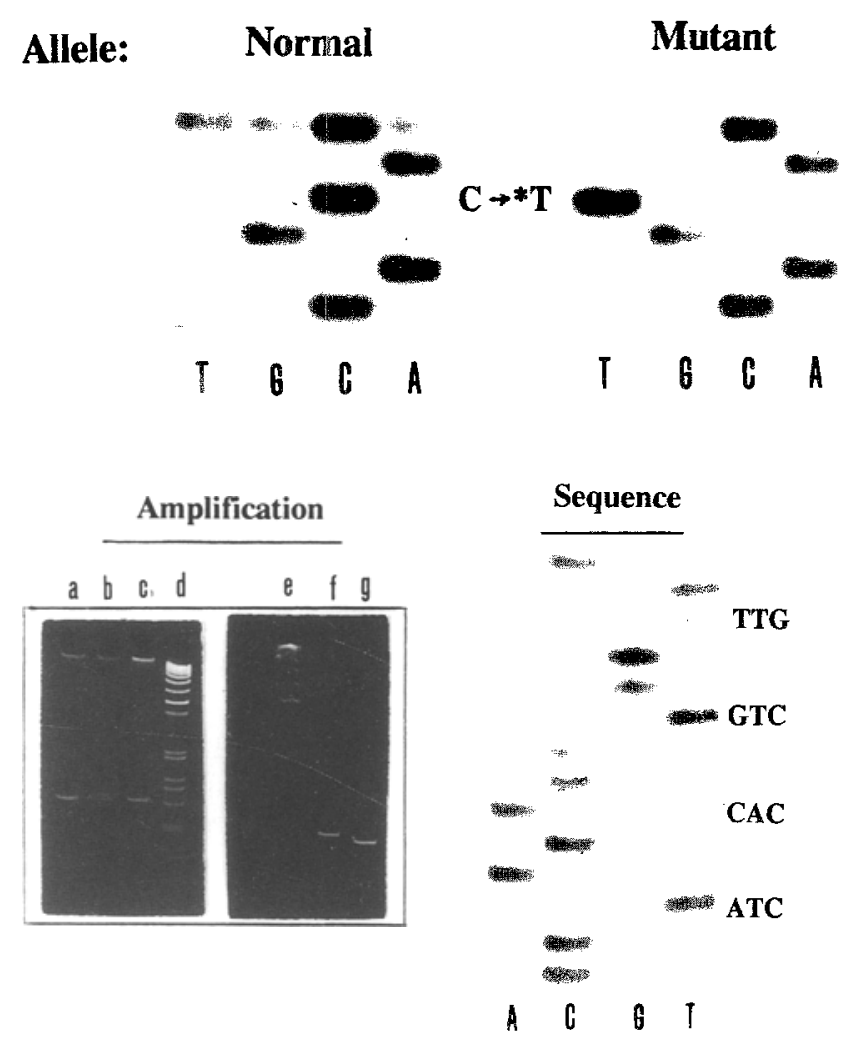

the paternal allele. Compared to control cells insulin binding to the mother's fibroblasts was reduced by $37 \%$. Insulin binding to the father's cells was significantly reduced by $63 \%$, which was still less than the binding to cells of PK $(89 \%)$ (Fig. 7).

\section{Discussion}

Characterization of mutant insulin receptors in patients with severe forms of insulin resistance [5, 12-17] has helped not only to elucidate structure-function relationships of the receptor protein, but also to understand its role in the pathogenesis of diabetes. The patient we have studied has a severe form of insulin-resistant diabetes and decreased cellular insulin binding. We describe two mutations in the extracellular domain of the insulin receptor in this patient. Thus, we provide further evidence that the Rabson-Mendenhall syndrome is causally related to mutations in the insulin receptor gene.

Specificity and affinity of a ligand to its receptor determines the activation of the cellular signalling cascade. Experiments using photoaffinity labelling [28] and chemical cross-linking [29] have shown that insulin binds to the $\alpha$-subunit. Insulin contact sites of the extracellular insulin receptor have been mapped to amino- $[30,31]$ and carboxyl-terminal [32] sequences of the $\alpha$-subunit as well as to the cysteine-rich region [33].

The described stop codon in exon 2 leads to a truncation of the receptor protein in the extracellular region after Ser-85 thereby deleting the entire receptor domains of hormone binding and protein kinase. Multiple nonsense mutations have been described in the insulin recep-

\section{Stop codon}

\section{CGA $\rightarrow$ TGA Arg-86}

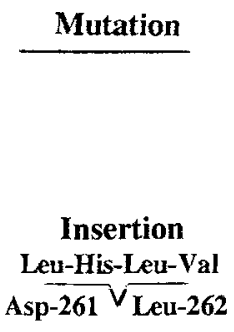

tor gene [34-38], most of which appeared to be associated with decreased levels of mRNA [35-38]. However, similar to the nonsense mutation at codon 672 in the paternal allele of leprechaun Ark-1 [34], direct cDNA sequencing of our patient showed that the allele with the nonsense mutation at codon Arg-86 is expressed almost to the same degree as the other insulin receptor allele.

The other mutant insulin receptor allele of PK contains an in-frame insertion mutation of four amino acids between Asp-261 and Leu-262. This is the first insertion mutation identified in the insulin receptor gene. A search in the European Molecular Biology Laboratory gene bank using the sequence of the inner 10 of the 12 inserted bp revealed a full match to nucleotide sequences of transcription factor NF-1 [39] and human non-erythroid $\alpha$-spectrin [40]. The four amino acids are mainly hydrophobic and are inserted between two cysteine residues (Cys-259 and Cys-266). Interestingly, this receptor sequence is part of a region which has no homology to the IGF-I receptor [4143] and therefore might play an essential role in determining ligand specificity. Studies of ligand binding by chimeric insulin/IGF-I receptors indicate that the region between amino acid residues 230 and 285 in the insulin receptor might be part of the domain determining ligand specificity [33]. The structural alterations in this receptor region might affect insulin receptor binding of IGF-I. However, partially purified insulin receptors of $P K$ were not autophosphorylated by incubation with IGF-I, indicating that IGF-I cannot activate the insulin receptor kinase in these cells. Several missense mutations have been characterized in the $\mathrm{N}$-terminal $\alpha$-subunit of the insulin receptor which are all associated with incomplete processing and defective transport $[36,44-48]$ to the plasma membrane. Cor- 


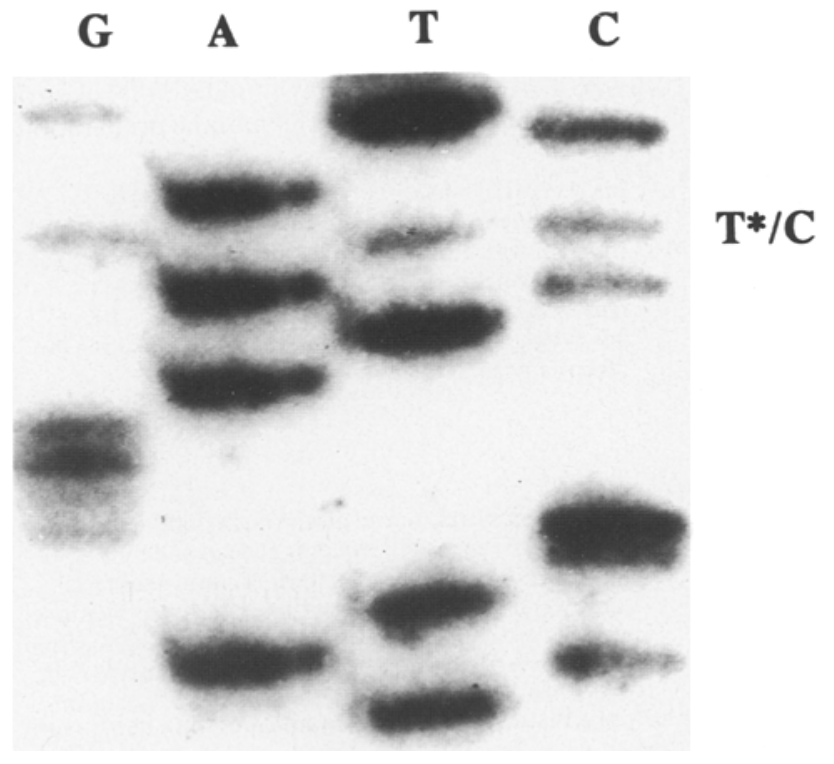

Fig.6. Partial nucleotide sequence of the patient's insulin receptor cDNA obtained from fibroblasts. Total RNA of fibroblasts were isolated, reverse transcribed to cDNA and amplified by polymerase chain reaction (PCR) using primers for the region corresponding to exon 2. After amplification the PCR products were sequenced directly. Both alleles are expressed, since both DNA sequences the wild type (CGA) and the mutated one (TGA) are observed

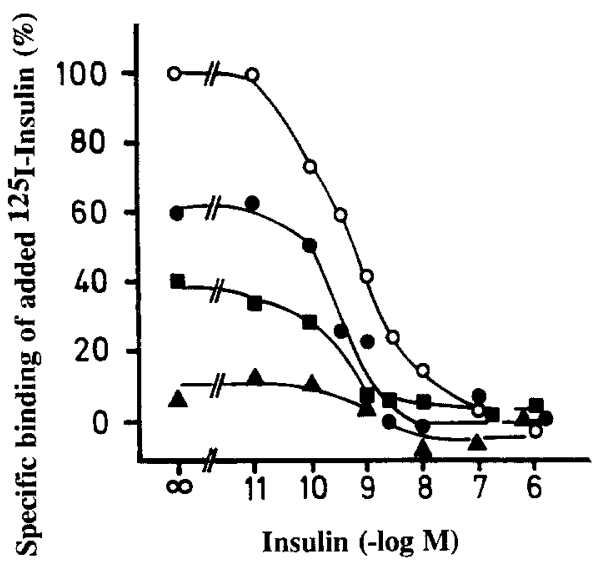

Fig. 7. Binding of ${ }^{125} \mathrm{I}$-insulin to fibroblasts from patient $\mathrm{PK}(\boldsymbol{\Delta})$, the mother (O), the father ( $\mathbf{E})$, and a control subject (O). Displacement curves are shown of bound radioactive insulin by increasing levels of non-radioactive insulin. Specific tracer binding of control cells represent $100 \%$ of binding. Cells were incubated with insulin at $4^{\circ} \mathrm{C}$ for $16 \mathrm{~h}$. Means of duplicate determinations of one representative experiment are shown. A total of four separate experiments were performed

respondingly, preliminary observations using transient transfections of in vitro mutated insulin receptor cDNA in cos cells indicate that the described in-frame insertion of four amino acids in the extracellular domain of the insulin receptor impairs proper intracellular receptor processing and transport to the plasma membrane (E. van der Vorm, unpublished observations).

Direct cDNA sequencing of reversed transcribed and amplified RNA indicate that both mutant insulin receptor alleles are expressed in fibroblasts of PK. Since the stop codon allele will most likely not produce a functioning protein the receptor oligomers of PK contain probably only insertion mutated $\alpha$-subunits. The mother, who is heterozygous for the stop codon, exhibits a moderate reduction in insulin binding most likely caused by a decreased number of functional intact insulin receptors encoded by the wild-type allele. The father appears to be not only genetically but also biochemically heterozygous for the insertion mutation exhibiting significantly decreased insulin binding in fibroblasts, but not to the same degree as PK.

The patient did not exhibit the typical features of leprechaunism such as early death, extreme hyperinsulinaemia and fasting hypoglycaemia. When both the clinical phenotype and abnormalities in plasma glucose levels are considered, it appears to be more likely that PK suffered from Rabson-Mendenhall syndrome [49, 50], characterized by less severe insulin resistance, death near puberty, and abnormal dentition. The insulin receptor gene has been sequenced in two other patients with Rabson-Mendenhall syndrome. One patient [36] was also compound heterozygous. Similar to PK this patient RM- 1 had a nonsense mutation at codon 1000 and a missense mutation in the amino-terminal extracellular receptor domain at codon 15. The missense mutation causes retardation of posttranslational receptor processing and transport rate to the plasma membrane, as well as five-fold reduction in the affinity of the insulin receptor to insulin [45].

In the past different genetic syndromes of severe insulin resistance have been described on the basis of clinical features. Recently, molecular genetics of the insulin receptor show that different mutations in the insulin receptor gene cause different or similar alterations in the structure-function relationship of the receptor protein and thereby in insulin action. Increasing evidence indicates that the degree of functional disturbance in the cellular pathway of insulin action dictates the clinical picture of insulin-resistant patients. The most severe structural alterations caused by homozygous and compound heterozygous mutations are found in patients with leprechaunism and in Rabson-Mendenhall syndrome. However, it is interesting to note that PK had only a relatively mild degree of insulin resistance despite the severe cellular binding defect and the complete absence of insulin-stimulated receptor autophosphorylation. The residual stimulatory effect of insulin on glucose uptake seen in patient's fibroblasts is probably mediated by hormone binding to the IGF-I receptor. A similar situation is seen with fibroblasts of leprechaun G [44] and Winn-1 [36]. The reason why a similar functional loss of insulin receptor can result in leprechaunism or Rabson-Mendenhall syndrome is unknown and additional factors may contribute to the pathogenesis of the full leprechaun phenotype.

Acknowledgements. D. Müller-Wieland and E. R. van der Vorm contributed equally to this article. This work was supported by the Deutsche Forschungsgemeinschaft (Mu 715/3-1 and SFB 232) and by grants from The Netherlands Organization for the Advancement of Pure Research (NWO) through the Foundation of Medical Research (MEDIGON) and the Diabetes Fond Nederland. We thank Ms A. Kuipers, Ms M. Munck, Ms E. Tourbier, and Ms S. Kellner for their excellent technical assistance. We would like to thank Drs. W. Möller and H.M. J. Krans for support and discussion. 


\section{References}

1. Kahn CR (1980) Role of insulin receptors in insulin-resistant states. Metabolism 29: 455-466

2. Olefsky JM, Koltermann OG (1981) Mechanisms of insulin resistance in obesity and noninsulin-dependent (type II) diabetes. Am J Med 70: 151-168

3. Reaven GM (1988) Role of insulin resistance in human disease. Diabetes 37: 1595-1607

4. Caro JF, Dohm LG, Pories WJ, Shinha MK (1989) Cellular alterations in liver, skeletal muscle, and adipose tissue responsible for insulin resistance in obesity and type II diabetes. Diabetes Metab Rev 5: 665-689

5. Moller DE, Flier JS (1991) Insulin resistance-mechanisms, syndromes, and implications. N Engl J Med 325: 938-948

6. Kahn CR (1985) The molecular mechanism of insulin action. Ann Rev Med 36: 429-451

7. Rosen O (1987) After insulin binds. Science 237: 1452-1458

8. Kahn CR, White MF (1988) The insulin receptor and the molecular mechanism of insulin action. J Clin Invest 82:1151-1156

9. Olefsky JM (1990) The insulin receptor: a multifunctional protein. Diabetes 39: 1009-1016

10. Goldfine ID (1987) The insulin receptor: molecular biology and transmembrane signaling. Endocrine Rev 8: 235-255

11. White MF, Kahn CR (1986) The insulin receptor and tyrosine phosphorylation. The Enzymes XVII: 247-310

12. Taylor SI, Cama A, Accili D et al. (1991) Molecular genetics of insulin resistant diabetes mellitus. J Clin Endo Metab 73: 11581163

13. Taylor SI, Kadowaki T, Kadowaki H, Accili D, Cama A, McKeon C (1990) Mutations in insulin receptor gene in insulin-resistant patients. Diabetes Care 13:257-279

14. O'Raihilly S, Moller DE (1992) Mutant insulin receptors in syndromes of insulin resistance. Clin Endocrinol 36: 121-136

15. Flier JS (1992) Lilly lecture: Syndromes of insulin resistance: from patient to gene and back again. Diabetes 41:1207-1219

16. Taylor SI, Cama A, Accili D et al. (1992) Mutations in the insulin receptor gene. Endocrine Rev 13: 566-595

17. Taylor SI (1992) Lilly lecture: Molecular mechanisms of insulin resistance: lessons from patients with mutations in the insulin-receptor gene. Diabetes 41: 1473-1490

18. Maassen JA, Krans HMJ, Möller W (1987) The effect of insulin, serum and dexamethasone on mRNA levels for the insulin receptor in the human lymphoblastoic cell line IM-9. Biochem Biophys Acta 930: 72-78

19. Rüdiger HW, Ahrens P, Dreyer M, Frorath B, Löffel C, SchmidtPreuß U (1985) Impaired insulin-induced RNA synthesis secondary to a genetically defective insulin receptor. Hum Genet 69: $76-78$

20. Maassen JA, Klinkhamer MP, Odink RJH et al. (1988) Improper expression of insulin receptors on fibroblasts from a leprechaun patient. Eur J Biochem 172: 725-729

21. Saiki RK (1990) Amplification of genomic DNA. In: Innis MA, Gelfand DH, SninskyJJ, White TJ (eds) PCR protocols: a guide to methods and applications. Academic Press, New York, pp 13-20

22. Chomczynski P, Sacchi N (1987) Single-step method of RNA isolation by acid guanidium thiocyanate phenol chloroform extraction. Anal Biochem 162: 156-159

23. Kawasaki ES, Wang AM (1989) Detection of gene expression. In: Erlich HA (ed) PCR Technology: principles and applications for DNA amplification. Stockton Press, New York London Tokyo Melbourne Hong Kong, pp 89-97

24. Casanova J-L, Pannetier C, Jaulin C, Kourilsky P (1990) Optimal conditions for directly sequencing double-stranded PCR products with sequenase. Nucl Acids Res 18: 4028

25. Davis LG, Dibner MD, Battey JF (1986) Basic methods in molecular biology. Elsevier, New York Amsterdam London, pp 219 232

26. Sanger F, Nicklen S, Coulson AR (1977) DNA sequencing with chain termination inhibitors. Proc Natl Acad Sci USA 74: 54635467
27. Seino S, Seino M, Bell GI (1990) Human insulin-receptor gene. Diabetes 39: 129-133

28. Yip CC, Yeung CWT, Moule ML (1980) Photoaffinity-labeling of insulin-receptor protein of liver plasma-membrane preparation. Biochem 19: 70-76

29. Pilch PF, Czech MP (1980) Subunit structure of the high-affinity insulin-receptor. Evidence for a disulfide receptor complex in fat-cell and liver plasma-membranes. J Biol Chem 255: 17221731

30. DeMeyts P, Gu J-L, Shymko RM, Kaplan BE, Bell GI, Whitakker $J$ (1990) Identification of a ligand-binding region of the human insulin receptor encoded by the second exon of the gene. Mol Endocrinol 4: 409-416

31. Wedekind F, Baer-Pontzen K, Bala-Mohan S, Choli D, Zahn H, Brandenburg D (1989) Hormone binding site of the insulin receptor: analysis using photoaffinity-mediated avidin complexing. Biol Chem Hoppe-Seyler 370: 251-258

32. Fabry M, Schaefer E, Ellis L, Kojro E, Fahrenholz F, Brandenburg D (1992) Detection of a new hormone contact site within the insulin receptor ectodomain by the use of a novel photoreactive insulin. J Biol Chem 267: 8950-8956

33. Yip CC (1992) The insulin-binding domain of insulin receptor is encoded by exon 2 and exon 3. J Cell Biochem 48: 19-25

34. Kadowaki T, Bevins CL, Cama A et al. (1988) Two mutant alleles of the insulin receptor gene in a patient with extreme insulin resistance. Science 240: 787-790

35. Kadowaki T, Kadowaki H, Taylor SI (1990) A nonsense mutation causing decreased levels of insulin receptor mRNA: detection by a simplified technique for direct sequencing of genomic DNA amplified by the polymerase chain. Proc Natl Acad Sci USA 87: 658-662

36. Kadowaki T, Kadowaki H, Rechler MMet al. (1990) Five mutant alleles of the insulin receptor gene in patients with genetic forms of insulin resistance. J Clin Invest 86: 254-264

37. Kusari J, Takata Y, Hatada E, Freidenberg G, Kolterman O, Olefsky JM (1991) Insulin resistance and diabetes due to different mutations in the tyrosine kinase domain of both insulin receptor gene alleles. J Biol Chem 266:5260-5267

38. Longo N, Lanley SD, Griffin LD, Elsas LJ II (1992) Reduced mRNA and a nonsense mutation in the insulin-receptor gene produce heritable severe insulin resistance. Am J Hum Gent 50: 998-1007

39. Santoro C, Mermod N, Andrews PC, Tjian R (1988) A family of human CCAAT-box-binding proteins active in transcription and DNA replication: cloning and expression of multiple cDNAs. Nature 334: 218-224

40. Moon RT, McMahon AP (1990) Generation of diversity of nonerythroid spectrins: multiple polypeptides are predicted by sequence analysis of cDNA's encompassing the coding region of human non erythroid alpha spectrin. J Biol Chem 265: 44274433

41. Ullrich A, Bell JR, Chen EY et al. (1985) Human insulin receptor and its relationship to the tyrosine kinase family of oncogenes. Nature 313: 756-761

42. Ebina Y, Ellis L, Jarnagin K et al. (1985) Human insulin receptor cDNA: the structural basis for hormone activated transmembrane signalling. Cell 40: 747-758

43. Ullrich A, Gray A., Tam AW et al. (1986) Insulin-like growth factor I receptor primary structure: comparison with insulin receptor suggests structural determinants that define functional specificity. EMBO J 5: 2503-2512

44. Klinkhamer MP, Groen NA, van der Zorn GCM et al. (1989) A leucine-to-proline mutation in the insulin receptor in a family with insulin resistance. EMBO J 8: 2503-2507

45. Kadowaki T, Kadowaki H, Accili D, Taylor SI (1990) Substitution of lysine for asparagine at position 15 in the $\alpha$-subunit of the human insulin receptor. J Biol Chem 265: 19143-19150

46. Van der Vorm ER, van der Zorn GCM, Möller W, Krans HMJ, Lindhout D, Maassen JA (1992) An arg for gly substitution at position 31 in the insulin receptor, linked to insulin resistance, inhibits receptor processing and transport. J Biol Chem 267: 66-71. 
47. Maassen JA, van der Vorm ER, van der Zorn GCM, Klinkhamer MP, Krans HMJ, Möller W (1991) A leucine to proline mutation at position 233 in the insulin receptor inhibits cleavage of the proreceptor and transport to the cell surface. Biochem 30: 1077810783

48. Accili D, Frapier C, Masthaf L et al. (1989) A mutation in the insulin receptor gene that impairs transport of the receptor to the plasma membrane and causes insulin-resistant diabetes. EMBO J 8: 2509-2517

49. Rabson SM, Mendenhall EN (1956) Familial hypertrophy of pineal body, hyperplasia of adrenal cortex, and diabetes mellitus. Am J Clin Pathol 26: 283-290

50. Taylor SI, Underhill LH, Hedo JA, Roth J, Rios MS, Blizzard RM (1983) Decreased insulin binding to cultured cells from a pa- tient with the Rabson-Mendenhall syndrome: dichotomy between studies with cultured lymphocytes and cultured fibroblasts. J Clin Endocrinol Metab 56: 856-861

Received: 30 March 1993

and in revised form: 10 June 1993

Dr. D. Müller-Wieland

Klinik II und Poliklinik für Innere Medizin

der Universität zu Köln

Joseph-Stelzmann-Str. 9

D-50924 Köln

Germany 